\title{
PROSPECTS, PROBLEMS AND POSSIBLE OPPORTUNITIES OF DIGITAL CURRENCY IN BANGLADESH
}

\author{
Humaira Begum \\ Assistant Professor \\ Department of Finance and Banking \\ Faculty of Business Studies \\ Hajee Mohammad Danesh Science and Technology University \\ Dinajpur-5200, Bangladesh \\ E-mail: humaira.begum@hstu.ac.bd
}

\begin{abstract}
This study attempts to present the prospects and problems of the digital currency in Bangladesh as well around the world. To demonstrate the prospect, price and trading volume of selected ten digital currencies being presented for observing the emerging the demand. From our country's perspective, the opinions of the respondents collected through questionnaires shed light on the prospect of digital currency in Bangladesh. Additionally, the study presents a systematic literature review (SLR) of research on digital currency. The review incorporated 11 articles presenting several issues related to digital currency. This study uses data from 2013 to 2020 for respective currencies related to price and trading volume. As well respondent's opinions collected through "questionnaires" are presented as per percentage. This study also makes theoretical contributions to the extant literature. The findings demonstrate that digital currency is now successfully traded in the most countries around the world except a few. Descriptive statistics of price and trading volume indicate that most of the variables are highly skewed with large outliers and kurtosis column shows that all the variables are near to normal distribution and investment regarding these values indicates a safe trading. The consents of 175 respondents present a positive attitude of the general public towards digital currency. The SLR methods suggest that a secure system and advanced technology should be attached to the block chain system to ensure better performance. The SLR findings also point out that digital currency is obviously a better alternative to cash, although it has some risks.
\end{abstract}

Keywords: Digital Currency, Prospects, Problems, Price, Trading Volume.

\section{INTRODUCTION}

New technologies are causing variable changes in the global economy; including the exchange of goods, services and resources. An important development in this transformation process is the emergence of digital currency. Digital currency is a balance or record stored on an Internetdistributed database, an electronic computer database, a digital file or a stored value card. An American computer scientist named David Chaum was the developer of the first concept of digital currency in 1983. In the early 1990s, various digital cash companies were founded and the bestknown of the digital currencies are DigiCash. The two major forms of digital currencies are- i) crypto currencies ii) virtual currencies. Today digital currency can create an added value in the Global economy. 
As of December 2019, there are more than 1,500 digital currencies (DCs) and this number is growing rapidly. This study cannot discuss the details of all these constructions here. And most digital currencies use blockchain technology. The specific function of some DCs can vary greatly. In addition, it is impossible to predict the future technological innovations that the makers of the new DC may use. An important feature of DC transactions is that DC units are moved directly from one location to another in the electronic ecosystem without the involvement of any intermediaries (such as financial institutions). A DC unit is usually stored at an electronic address with a unique public ID. Multiple addresses can be combined into one "electronic wallet". DC transactions are usually recorded chronologically in a public decentralized ledger, commonly referred to as a "blockchain." The ledger is made up of "blocks" that contain records of past transactions. The blockchain is run by the so-called "mining" community. A miner who provides the computing power needed to process a transaction and keep the system running. In return for their services, miners receive a small amount of DC units in the form of voluntary fees or newly excavated DC units.

Now the world enters into the era of virtual currencies, foreign exchanges are still regulated in Bangladesh by backdated rules like the Foreign Exchange Regulation Act, 1947. However, Bangladesh is moving towards developed countries, meeting the SDGs by taking several policies by the government (Banu et al., 2021). Six countries including Bangladesh (Algeria, Bolivia, Bangladesh, Ecuador, Nepal, and The Republic of Macedonia) totally banned cryptocurrencies. Bangladesh Bank warned in 2014 and published 'cautionary notice' in 2017 that Bitcoin violates the Foreign Exchange Regulatory Act, 1949, Money Laundering Prevention Act, 2012, and AntiTerrorism Act, 2009. Digital currency has the potential to generate benefits. There are some renowned companies such as Microsoft, Tesla, Lionsgate, Amazon, etc. use different kinds of digital currency. Bangladesh should allow the virtual transaction platform for transactions through the use of digital currencies to facilitate international trade in goods and services.

People are moving towards the use of various upgraded currency like electronic money which is a consequence of digitalization. Digital currency can cover the liquidity problem of a country. Digital currency may help to change the nature of money transactions in Bangladesh and may contribute positive impacts on Bangladesh's finance. Thus, it's high time to realize the importance of digital currency for digitalization in the financial sector.

The rapid spread of internet-based commerce and mobile technology facilitates the use of Digital currency (DC). Secure online payment systems such as PayPal and mobile payments and transfer solutions like M-Pesa are changing the ways of making payments for goods and services. The development of effective regulatory responses to DCs is still at an early stage. These currencies are difficult to regulate as they cut across the responsibilities of different agencies at the national and global levels. Different international bodies are playing an important role in identifying and discussing the risks posed by DCs and possible regulatory responses.

This study focuses on the overall prospects of digital currency, reveals the present scenario in Bangladesh, identifies the problems and risks in our country, and suggests some possible ways to use digital currency. In this study mostly the secondary data from valid online sources are used, to show the overall prospects of digital currency. Price fluctuations and trading volume by observing the top ten digital currencies ranked by coinmarketcap.com are used. As well the descriptive statistics of these currencies present the safe trading of them. For presenting the scenario of digital currency in Bangladesh particular secondary data regarding our country was not available. A structured questionnaire is used to collect primary data. Based on the response of 175 respondents I try to find some problems and expectations of the people regarding digital currency 
in Bangladesh. Study results show that the majority of the respondents want digital currency in Bangladesh although it has some risks associated with money laundering as well as chances of fraudulence.

Previously many studies were conducted but the prospect of Bangladesh regarding digital currency not been covered yet. This study has somehow been able to present this scenario. If this study results being considered, it will be helpful for the government as well as for the policymakers of our country to rethink the approval of digital currency by following the country successfully using digital currency.

\section{SYSTEMATIC LITERATURE REVIEW (SLR)}

This study presents a systematic literature review (SLR) of research on digital currency. This review incorporates 14 articles related to the digital currency, which are as follows:

Table 1. Systematic Literature Review (SLR)

\begin{tabular}{|c|c|c|c|}
\hline SL No & Title & Paper Type & Findings \\
\hline 1. & $\begin{array}{l}\text { Security of Crypto } \\
\text { currencies in block chain } \\
\text { technology: State-of-art, } \\
\text { challenges and future } \\
\text { purpose. }\end{array}$ & Article & $\begin{array}{l}\text { Ghosh et al. (2020) narrate that there } \\
\text { are several involvements of different } \\
\text { technologies in blockchain } \\
\text { (consensus methodology, forks and } \\
\text { facilitates with a detailed discussion) } \\
\text { for smart communication. They also } \\
\text { noted that improvements in security } \\
\text { and system networks may gain the } \\
\text { trust of the users. }\end{array}$ \\
\hline 2. & $\begin{array}{l}\text { Financial implications of } \\
\text { fourth industrial } \\
\text { revolution: Can bitcoin } \\
\text { improve prospects of } \\
\text { energy investment. }\end{array}$ & Article & $\begin{array}{l}\text { Su et al. (2020) revealed that the } \\
\text { transformation of society has } \\
\text { increased dramatically with the } \\
\text { ongoing or continuous progress of } \\
\text { blockchain, cloud computing, and so } \\
\text { on. Those technologies reduce the } \\
\text { transaction fees and liquidity costs. } \\
\text { Also noted is that bitcoin could be } \\
\text { considered as an asset and bitcoin has } \\
\text { more investment prospects. }\end{array}$ \\
\hline 3. & $\begin{array}{l}\text { Digital Currencies in } \\
\text { Financial Networks }\end{array}$ & Article & $\begin{array}{l}\text { Castrén et al. (2020) studied digital } \\
\text { currencies in financial networks } \\
\text { which highlighted the strong cross- } \\
\text { border links in financial network. } \\
\text { This study basically focused on the } \\
\text { shift of deposits of households and } \\
\text { non-financial corporations from the } \\
\text { banking sector to the digital currency } \\
\text { to figure out the responses on those } \\
\text { sectors. }\end{array}$ \\
\hline
\end{tabular}




\begin{tabular}{|c|c|c|c|}
\hline 4. & $\begin{array}{l}\text { Regulatory Issues of } \\
\text { Digital Currencies }\end{array}$ & Article & $\begin{array}{l}\text { Zhu and Fu (2020) focused on the } \\
\text { regulatory issues of digital } \\
\text { currencies, which revealed that with } \\
\text { the fast advancement of the internet } \\
\text { and electronic installment, digital } \\
\text { currency with block chain as the } \\
\text { innovation have steadily entered } \\
\text { individuals' horizon and have also } \\
\text { gotten the consideration of } \\
\text { government around the world. }\end{array}$ \\
\hline 5. & $\begin{array}{lr}\text { Digital } & \text { currency } \\
\text { forecasting with } & \text { chaotic } \\
\text { meta-heuristic } & \text { bio- } \\
\text { inspired signal processing } \\
\text { techniques. }\end{array}$ & Article & $\begin{array}{l}\text { Altan et al. (2019) found that there is } \\
\text { a scope to use hybrid models in } \\
\text { forecasting digital currency. Due to } \\
\text { the global economic crisis, } \\
\text { cryptocurrency forecasting has } \\
\text { become essential. }\end{array}$ \\
\hline 6. & $\begin{array}{l}\text { How to make a digital } \\
\text { currency on a block chain } \\
\text { stable. }\end{array}$ & Article & $\begin{array}{l}\text { Saito and Iwamura (2019) revealed } \\
\text { that, for the stabilization of the } \\
\text { market price of digital currencies, } \\
\text { there is a need for the systematic } \\
\text { technology. }\end{array}$ \\
\hline 7. & $\begin{array}{l}\text { The Impact of Digital } \\
\text { Currency on the Financial } \\
\text { System: Universal } \\
\text { Decentralized Digital } \\
\text { Currency, Is It Possible }\end{array}$ & Article & $\begin{array}{l}\text { Li et al. (2019) revealed that in } \\
\text { China, digital currency has a } \\
\text { substitution effect on current deposits } \\
\text { in the long term. Their study } \\
\text { suggested that based on the problems } \\
\text { of digital currency, such as the } \\
\text { decentralized supervision institution, } \\
\text { hacker attack, etc., a global digital } \\
\text { currency supervision system, } \\
\text { including two parts: national } \\
\text { supervision and international } \\
\text { supervision could be helpful to the } \\
\text { establishment of the supervision } \\
\text { system of digital currency. }\end{array}$ \\
\hline 8. & $\begin{array}{l}\text { Decarburizing Bitcoin: } \\
\text { Law and policy choices } \\
\text { for reducing the energy } \\
\text { consumption of block- } \\
\text { chain technology and } \\
\text { digital currencies. }\end{array}$ & Article & $\begin{array}{l}\text { Truby (2018) revealed that digital } \\
\text { currency development can help to } \\
\text { solve problems related to climate } \\
\text { change. It also helps to generate the } \\
\text { fund for climate finance programme. } \\
\text { Digital currencies somehow may } \\
\text { harm the industry, if sustainable } \\
\text { alternatives have not been developed. }\end{array}$ \\
\hline 9. & $\begin{array}{l}\text { Time-varying causality } \\
\text { between equity and } \\
\text { currency returns in the }\end{array}$ & Article & $\begin{array}{l}\text { Kanda et al. (2018) Noted that } \\
\text { sometimes they found information } \\
\text { spill over evidence between equity }\end{array}$ \\
\hline
\end{tabular}




\begin{tabular}{|c|c|c|c|}
\hline & $\begin{array}{l}\text { United Kingdom: } \\
\text { Evidence from over two } \\
\text { centuries of data. }\end{array}$ & & $\begin{array}{l}\text { markets and currency markets and } \\
\text { sometimes they didn't. }\end{array}$ \\
\hline 10. & $\begin{array}{l}\text { The role of secondary } \\
\text { sources on the taxation of } \\
\text { digital currency (Bitcoin) } \\
\text { before IRS guidance was } \\
\text { issued. }\end{array}$ & Article & $\begin{array}{l}\text { Gross et al. (2017) narrated that there } \\
\text { must be need to involvement of } \\
\text { secondary sources, and bitcoin as a } \\
\text { digital currency reported as taxable } \\
\text { income. }\end{array}$ \\
\hline 11. & $\begin{array}{l}\text { The economics of Bitcoin } \\
\text { and similar private digital } \\
\text { currencies. }\end{array}$ & Article & $\begin{array}{l}\text { Dwyer (2015) stated that digital } \\
\text { currencies can trade } 24 / 7 \text { on } \\
\text { computerized market where there } \\
\text { might be no broker as well without } \\
\text { the intervention of financial } \\
\text { institutions like banks. Digital } \\
\text { currencies can cut the cost of } \\
\text { withdrawal of money. Digital } \\
\text { currencies will help the undermine } \\
\text { government's ability to gain } \\
\text { immense revenue from sustainable } \\
\text { inflation. }\end{array}$ \\
\hline 12. & $\begin{array}{l}\text { Financial Inclusion, } \\
\text { Digital Currency, and } \\
\text { Mobile Technology. }\end{array}$ & Book Chapter & $\begin{array}{l}\text { Sapovadia (2018) narrated in this } \\
\text { chapter that to regulate digital } \\
\text { currency, mobile technology is the } \\
\text { most effective media to cover non- } \\
\text { served population. He also } \\
\text { approaches the government to create } \\
\text { an expected regulation which will be } \\
\text { business friendly, fraud-proof, } \\
\text { affordable and so on. }\end{array}$ \\
\hline 13. & $\begin{array}{l}\text { Virtual currencies under } \\
\text { EU } \\
\text { laundering. }\end{array}$ & Article & $\begin{array}{l}\text { Vandezande (2017) Narrated that } \\
\text { according to EU-wide legislation the } \\
\text { legal framework can't be applied to } \\
\text { all categories of virtual currencies. } \\
\text { European commission proposed an } \\
\text { amend for anti-money laundering } \\
\text { rules which effects the virtual } \\
\text { currency exchange platforms. }\end{array}$ \\
\hline
\end{tabular}

\section{METHODOLOGY}

The study is conducted by using both primary and secondary sources of data. The details of this research method are as follows:

\section{Sample Selection}

For observing the overall prospect of digital currency, this study uses the top ten digital currencies ranked by coinmarketcap.com. To demonstrate the scenario of digital currency both secondary and 
primary data have been used. This current study conducts a questionnaire survey that covers 175 respondents from different groups of people.

\section{Selection Period}

For each currency, there were variations of time. The time frame starts from 2013 and ends up the last data available for the year 2021. I collected this secondary data from coinmarketcap.com. For collecting primary data, I prepared a structured questionnaire and gathered responses from 175 respondents regarding their views and opinions about digital currency.

Table 2. Description of the data

\begin{tabular}{|c|c|c|}
\hline Name of digital currencies & Starting date & Number of observations \\
\hline Bitcoin & 28 -Apr-2013 & 2970 \\
\hline Ethereum & 7-Aug-2015 & 2140 \\
\hline Tether & 25 -Feb-2015 & 2297 \\
\hline Binance cash & 25-Jul-2017 & 1421 \\
\hline Cardano & 1-Oct-2017 & 1353 \\
\hline Dogecoin & 15-Dec-2013 & 2739 \\
\hline XRP & 4-Aug-2013 & 2872 \\
\hline USD coin & 8-Oct-2018 & 981 \\
\hline Polkadot & 20-Aug-2020 & 299 \\
\hline Uniswap & 17-Sep-2020 & 271 \\
\hline \multicolumn{2}{|r}{} \\
\hline
\end{tabular}

\section{Source of Data}

As mentioned earlier in this study, I used coinmarketcap.com as a trustable source for secondary data as well as some data being collected from the different financial institutions that previously used digital currency in Bangladesh. Primary data are collected through a questionnaire from 175 respondents.

\section{Descriptive Statistics}

\section{RESULT AND DISCUSSION}

Table 3 shows the descriptive statistics of daily price of Bitcoin, Ethereum, Tether, Binance cash, Cardano, Dogecoin, XRP, USD coin, Polkadot, and Uniswap. In the first column, we can see the mean value. The second column displays the standard deviation of the observations. The third and fourth columns indicate the minimum and maximum values. The fifth column represents the skewness coefficients. The last column shows the kurtosis coefficient respectively.

Table 3. Descriptive statistics of the price of digital currencies

\begin{tabular}{|c|c|c|c|c|c|c|}
\hline & Mean & Std. & Min & Max & Skew. & Kurt. \\
\hline Bitcoin & 7.5491 & 1.7068 & 4.2258 & 11.058 & .0734 & 1.789 \\
\hline Ethereum & 4.6254 & 2.0788 & -.8439 & 8.3353 & -.8486 & 2.926 \\
\hline Tether & .00042 & .01793 & -.4942 & .19062 & -17.60 & 5.177 \\
\hline
\end{tabular}




\begin{tabular}{|c|c|c|c|c|c|c|}
\hline Binance cash & 2.7843 & 1.3630 & -2.3025 & 6.5157 & -.00562 & 5.461 \\
\hline Cardano & 2.2068 & 1.1088 & -3.9120 & .83724 & .9594 & 3.121 \\
\hline Dogecoin & -6.8042 & 1.7182 & -9.3465 & -.3856 & .8978 & 4.323 \\
\hline XRP & 2.8488 & 1.9742 & -5.8745 & 1.2178 & -.0330 & 1.307 \\
\hline USD coin & .00342 & .00707 & -.03045 & .0392 & 1.534 & 7.650 \\
\hline Polkadot & 2.5125 & .92605 & 1.0577 & 3.8701 & .0337 & 1.258 \\
\hline Uniswap & 2.3807 & 1.0263 & .65752 & 3.7649 & -.1303 & 1.274 \\
\hline
\end{tabular}

The average prices (log form) are 7.54 for Bitcoin, 4.62 for Ethereum, closer to zero for Tether and USD coin, 2.78 for Binance cash, 2.20 for Cardano, -6.80 for Dogecoin, 2.85 for XRP, 2.51 for Polkadot, and 2.38 for Uniswap. The data of Bitcoin, Binance cash, XRP, Polkadot, and Uniswap are fairly symmetrical whereas data of Ethereum are moderately skewed and the rest are highly skewed. On the contrary, the kurtosis values of all the variables indicate too peaked. The variables Tether, Binance cash, Dogecoin, and USD coin imply a leptokurtic distribution since it has heavy tails on either side, indicating large outliers. Bitcoin, Ethereum, XRP, Polkadot, Cardano, and Uniswap have a mesokurtic distribution and follow nearly normal distribution $[\boldsymbol{N}(\boldsymbol{\mu}$, $\left.\left.\sigma^{2}\right)\right]$.

Table 4. Descriptive statistics of the trading volume of digital currencies

\begin{tabular}{|c|c|c|c|c|c|c|}
\hline & Mean & Std. & Min & Max & Skew. & Kurt. \\
\hline Bitcoin & 20.672 & 3.011 & 14.865 & 26.583 & -.1000 & 1.410 \\
\hline Etherem & 20.398 & 3.299 & 11.53 & 25.159 & -.8499 & 2.539 \\
\hline Tether & 18.948 & 5.898 & .6931 & 26.354 & -.7886 & 2.471 \\
\hline Binance cash & 18.799 & 1.779 & 9.136 & 23.612 & -.4796 & 4.604 \\
\hline Cardano & 18.874 & 1.768 & 14.369 & 23.675 & .4989 & 2.988 \\
\hline Dogecoin & 15.308 & 3.092 & 9.722 & 24.963 & .3173 & 2.380 \\
\hline XRP & 17.374 & 3.955 & 9.025 & 24.332 & -.1535 & 1.409 \\
\hline USD coin & 19.255 & 1.745 & 11.597 & 22.809 & -1.036 & 4.454 \\
\hline Polkadot & 21.031 & .9804 & 17.703 & 23.032 & -.3350 & 2.410 \\
\hline Uniswap & 20.584 & .6694 & 19.059 & 22.575 & .5393 & 3.1405 \\
\hline
\end{tabular}

Table 4 shows the descriptive statistics of trading volume of Bitcoin, Ethereum, Tether, Binance cash, Cardano, Dogecoin, XRP, USD coin, Polkadot and Uniswap. In first column, we can see the mean value. Second column displays the standard deviation of the observations. Also the third and fourth columns indicate the minimum and maximum value. Fifth column represent the skewness coefficients. The last column shows the kurtosis coefficient respectively. The mean of all the variables is ranging from 17.00 to 21.00. The highest value is of Polkadot (21.03) and the lowest is of XRP (17.37). Most of the variables are highly skewed with large outliers and kurtosis column shows that all the variables are near to normal distribution and investment regarding these values indicates a safe trading.

\section{Prospects of Digital Currency in Bangladesh through the Questionnaire Survey}

A different group of people based on their occupation, participate in this survey. This study uses the percentage of response by the participants. Secondary data can be used to supplement the 
analysis with a purposive study. This study collected opinions from 175 respondents through a structured questionnaire.

Figure 1 showing that among 175 respondents, 7 are freelancer, 3 are web developer, 8 are online marketer, 1 is importer/exporter and 156 are from other occupations. Figure 2 showing that 144 respondents heard about digital currency, 12respondents not yet and 17 respondents are confused about their opinion regarding this question.

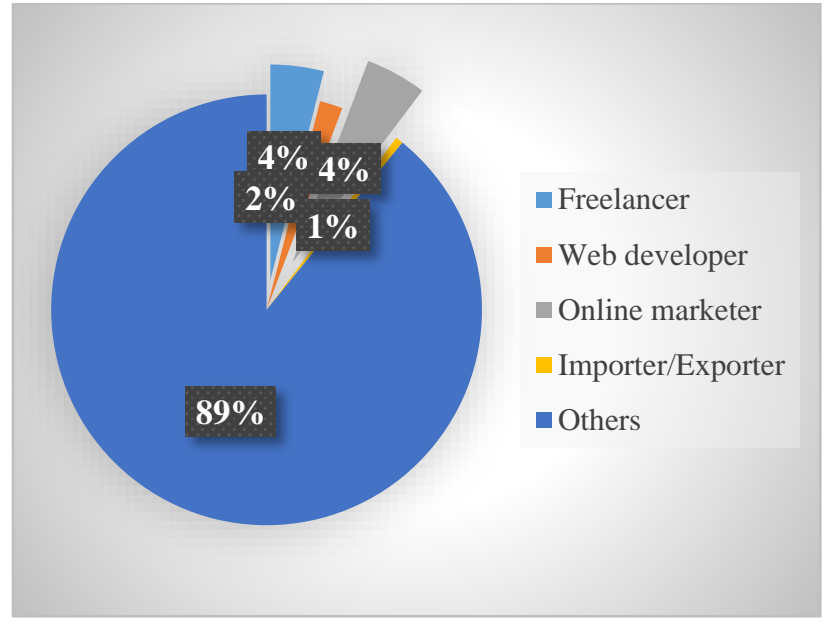

Figure 1. Occupational Status

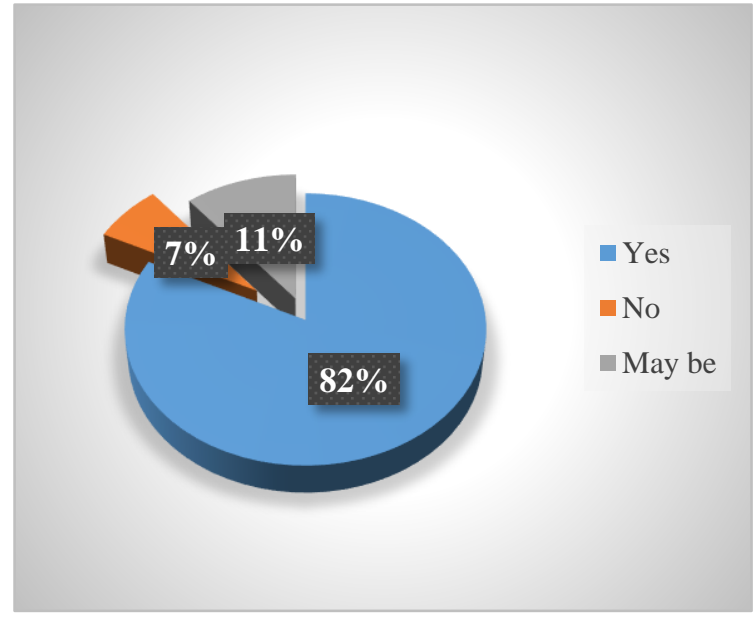

Figure 2. Have you ever heard about digital currency?

Figure 3 shows that 20 respondents know about digital currency from newspapers, 112 are from social media, 12 are from family and friends, 11 are from their own using purpose and 20 are from other media. From figure 4 we found that 78 respondents agree with the statement, 27 somehow agree, 57 are strongly agree, 8 are neutral, 1 respondent disagree, 2 somehow disagrees and 2 strongly disagrees.

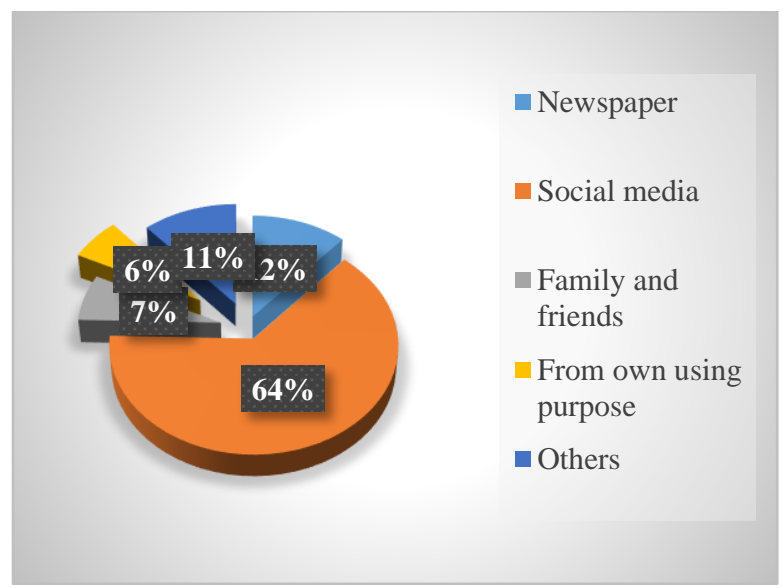

Figure 3. Sources from where they know about digital currency?

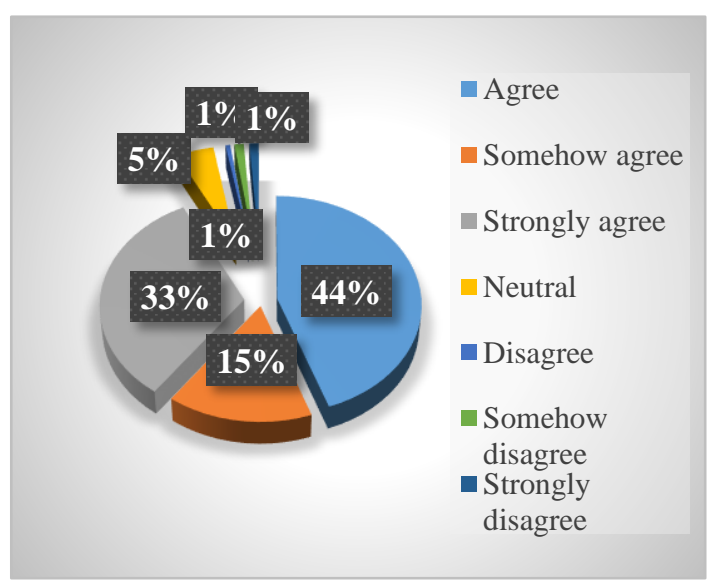

Figure 4. Digital currency may help fast transactions? 
From figure 5 we found that 77 respondents agree, 29 somehow agree, 42 strongly agree, 15 are neutral, 6 disagrees, 4 somehow disagree and 2 strongly disagree. From figure 6 we found that 83 respondents agree, 24 somehow agree, 26 strongly agree, 25 are neutral, 9 disagree, 4 somehow disagree and 4 strongly disagree.

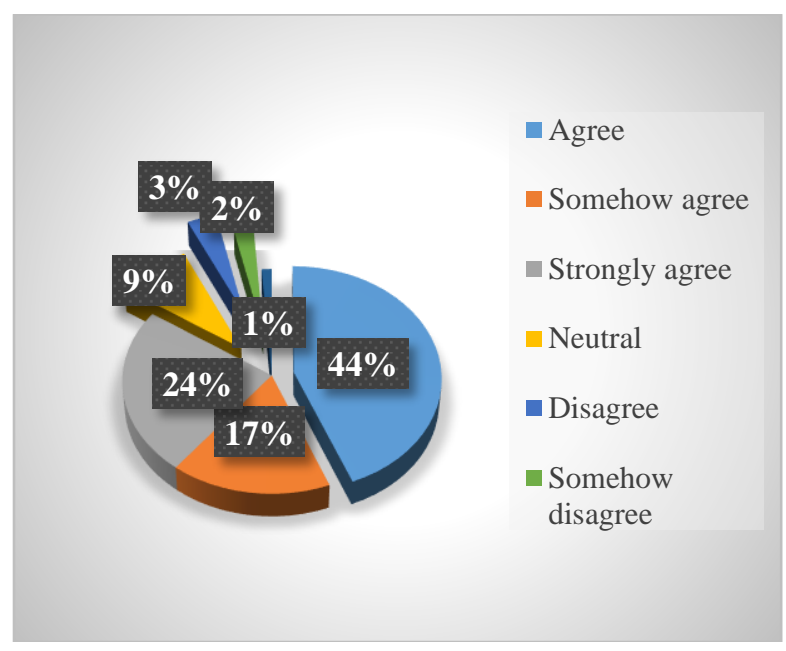

Figure 5. Digital currency may be the best alternative of cash?

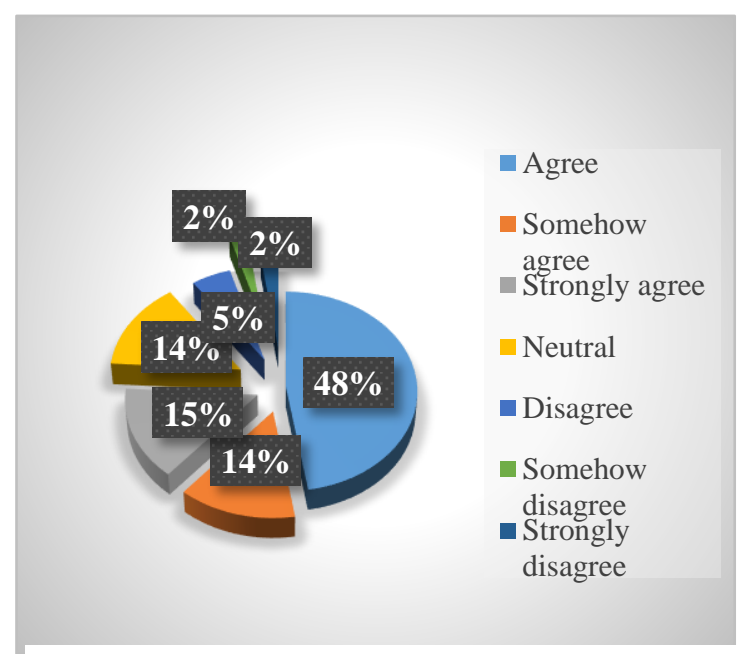

Figure 6. Redemption of digital currency may be easier than cash?

From figure 7 this study found that 74 respondents agree, 15 somehow agree, 72 strongly agree, 9 are neutral, 3 disagrees, 1 somehow disagrees and 1 strongly disagrees. From figure 8, this study found that 52 respondents agree, 34 somehow agree, 32 strongly agree, 39 are neutral, 10 disagrees, 6 somehow disagrees and 2 strongly disagrees.

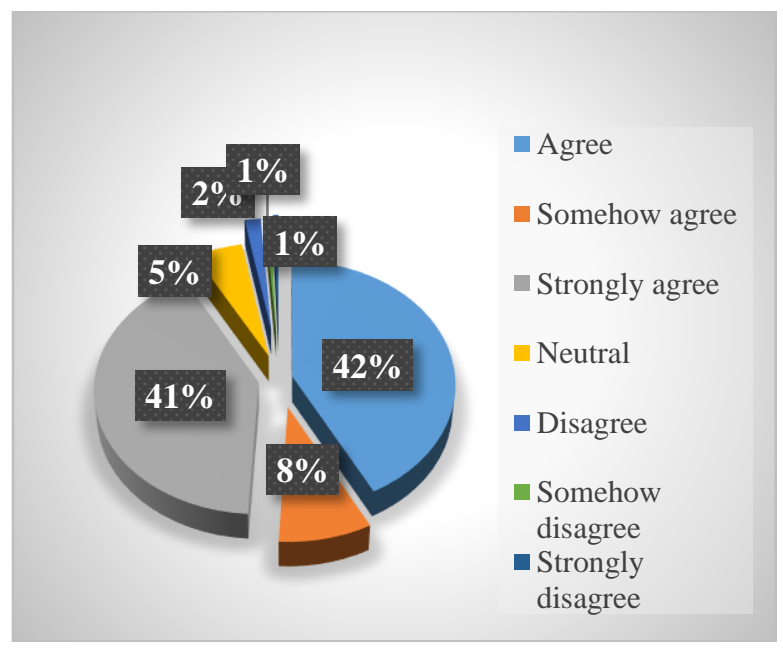

Figure 7. Digital currency may be the easy way for online payments.

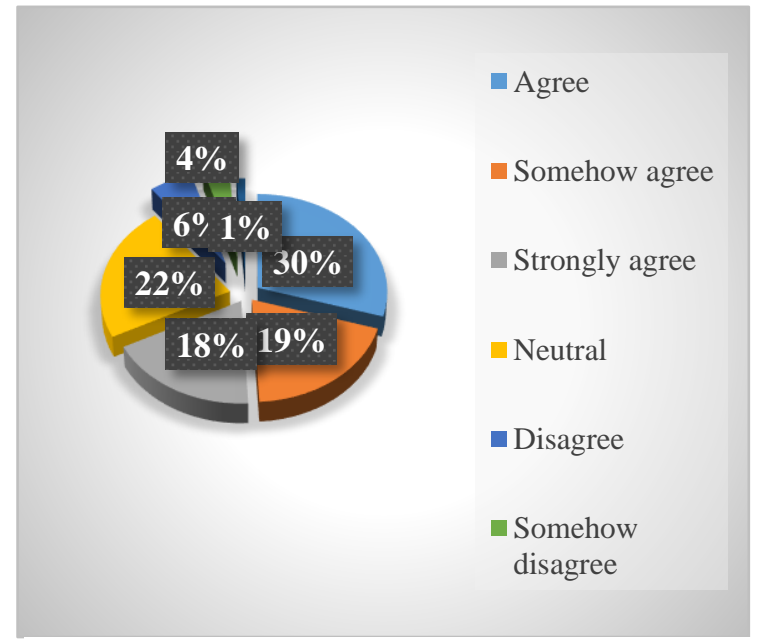

Figure 8. By using digital currency may occur money scam. 
From figure 9, we found that 46 respondents agree, 33 somehow agree, 24 strongly agree, 31 are neutral, 19 disagrees, 8 somehow disagrees and 14 strongly disagrees. From figure 10, we conclude that 49 respondents agree, 26 somehow agree, 29 strongly agree, 35 are neutral, 20 disagrees, 10 somehow disagrees and 6 strongly disagrees.

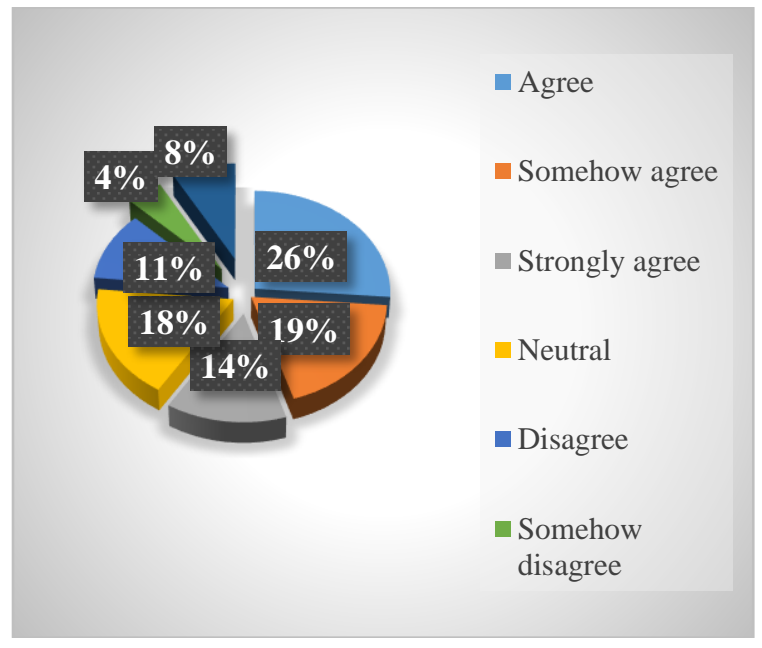

Figure 9. Digital currency may increase the risk of transaction.

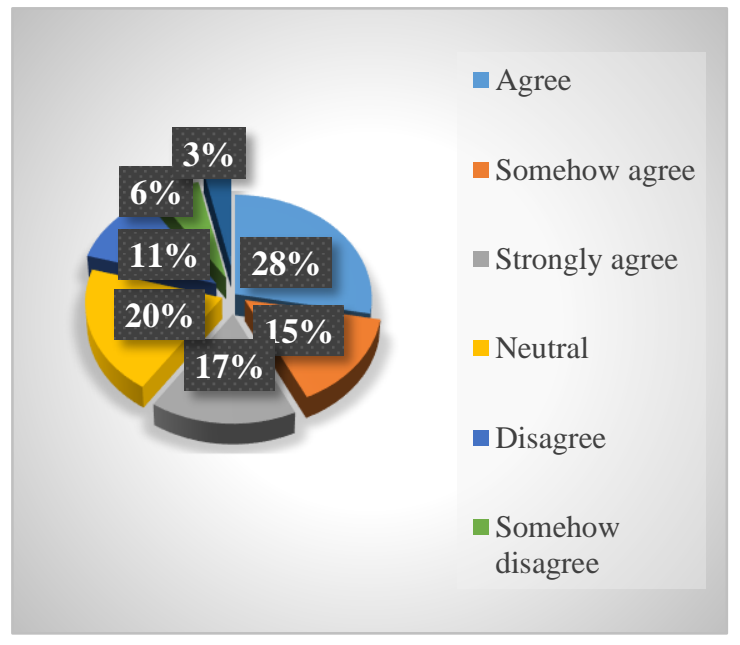

Figure 10. Digital currency may increase fraudulence.

From figure 11, we found that 83 respondents agree, 23 somehow agree, 47 strongly agree, 12 are neutral, 4 disagrees, 1 somehow disagrees and 5 strongly disagrees. From figure 12, we found that 65 respondents agree, 23 somehow agrees, 59 strongly agrees, 15 are neutral, 9 disagrees, 2 somehow disagrees and 2 are strongly disagree.

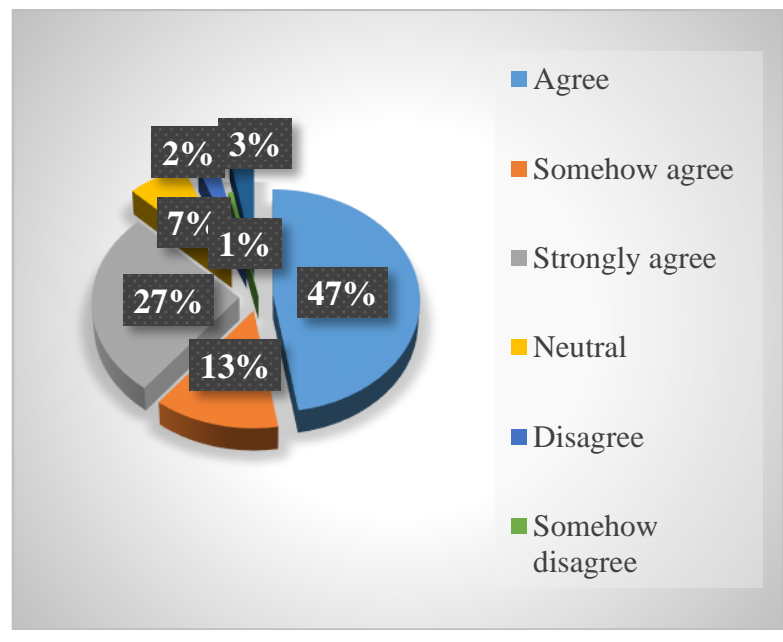

Figure 11. If Bangladesh Govt allowed digital currencies, it will help you for getting your payments faster?

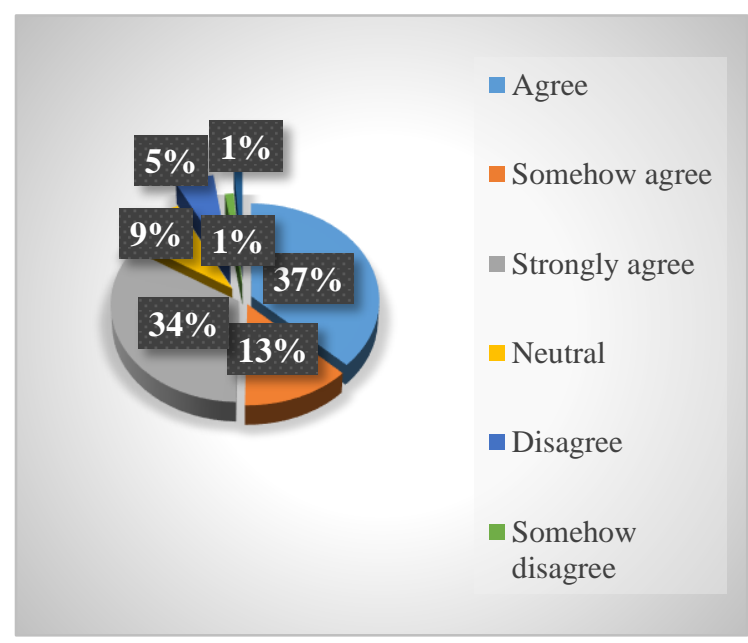

Figure 12. In Bangladesh Digital Currency transaction is risky because of the lack of technology? 
From figure 13, we found that 68 respondents agree, 23 somehow agree, 42 strongly agree, 28 are neutral, 10 disagrees, 5 somehow disagrees and 0 strongly disagrees. From figure 14, we found that 70 respondents agree, 19 somehow agree, 43 strongly agree, 34 are neutral, 4 disagrees, 2 somehow disagrees and 3 strongly disagrees.

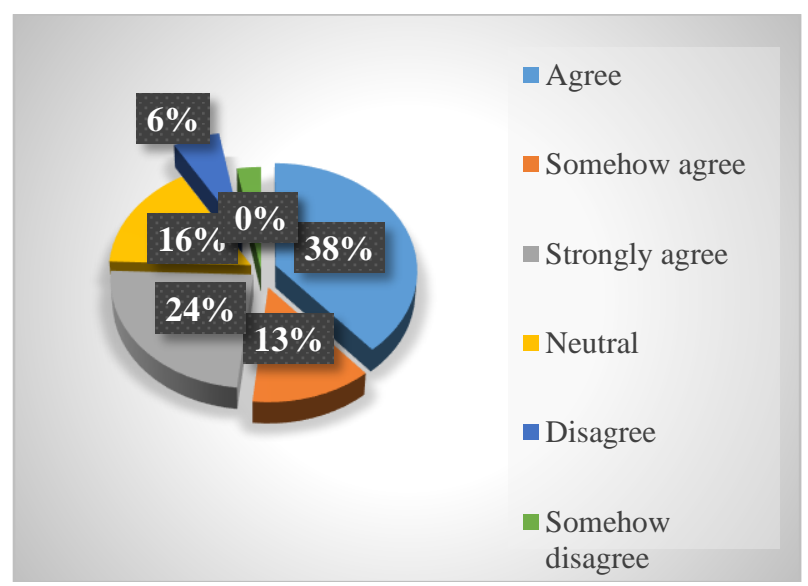

Figure 13. Digital currency increases the chances of money laundering through?

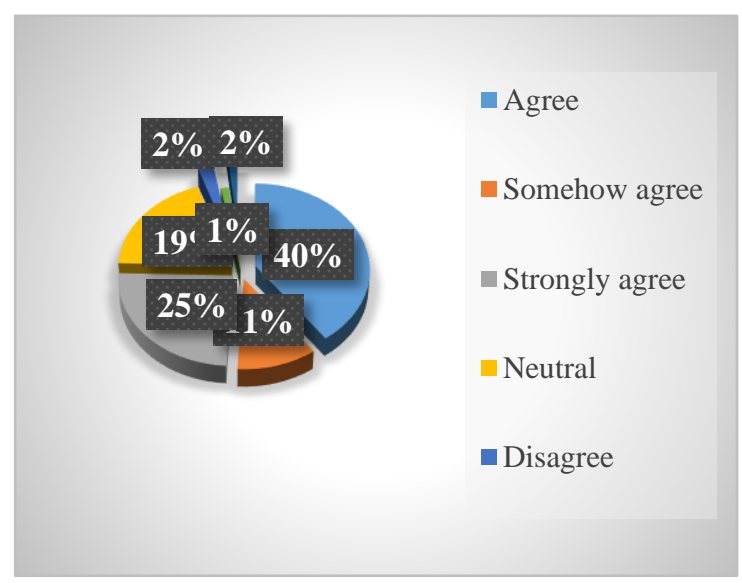

Figure 14. Acceptance of digital currency will help to increase the remittance of Bangladesh?

From figure 15, we found that 59 respondents agree, 32 somehow agree, 20 strongly agree, 36 are neutral, 16 disagrees, 7 somehow disagrees and 6 strongly disagrees. From figure 16, we found that 62 respondents agree, 24 somehow agree, 34 are strongly agree, 38 are neutral, 5 disagrees, 5 somehow disagree and 7 strongly disagree.

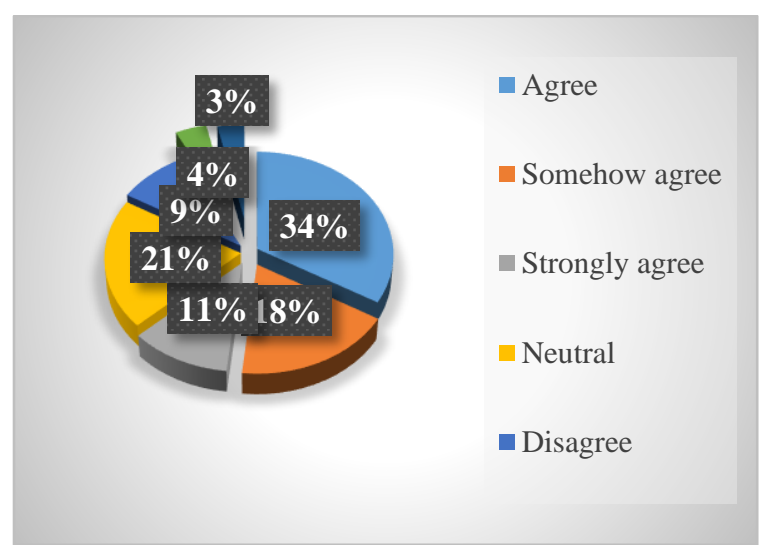

Figure 15. Fraudulence will increase if Bangladesh get acceptance of Digital Currency?

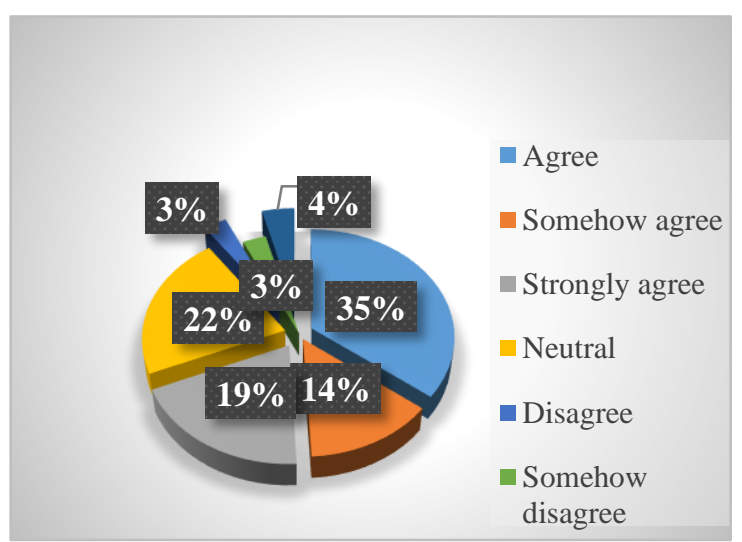

Figure 16. Lack of Digital Currency in Bangladesh creates more cost for Freelancer, Web developer, online marketer etc.? 


\section{FINDINGS}

Findings from the secondary data of ten digital currencies are:

- The data of Bitcoin, Binance cash, XRP, Polkadot, and Uniswap are fairly symmetrical whereas data of Ethereum are moderately skewed and the rest are highly skewed. On the contrary, the kurtosis values of all the variables indicate too peaked. The variables Tether, Binance cash, Dogecoin and USD coin imply a leptokurtic distribution since it has heavy tails on either side, indicating large outliers. Bitcoin, Ethereum, XRP, Polkadot, Cardano, and Uniswap have a mesokurtic distribution and follow nearly normal distribution $[\boldsymbol{N}(\boldsymbol{\mu}$, $\left.\left.\sigma^{2}\right)\right]$.

- Most of the variables are highly skewed with large outliers and kurtosis column shows that all the variables are near to normal distribution and investment regarding these values indicates a safe trading.

By conducting a questionnaire survey this current study considers 175 samples from different occupations such as freelancer, online marketer, web developer, and others. They answered several questions based on their opinion and expectation regarding digital currency in Bangladesh. This study results revealed that:

- About $92 \%$ of respondents agree that digital currency may be helpful for a fast transaction, although $85 \%$ of people believe that digital currency can be the best alternatives to cash, further $77 \%$ of respondents think that redemption of digital currency may be easier than cash, besides that $91 \%$ people do believe that online payments will be easier with the help of digital currency. So, the above-mentioned opinions conclude that approximately $80 \%$ of people are taking digital currency positively.

Having those positive opinions peoples are also highly concerned about some negative issues regarding digital currency-

- About $67 \%$ of respondents express that there is a chance of money scam using digital currency, $59 \%$ of people are worried about transaction risks, and $60 \%$ of respondents show concern for the threat of fraudulence through digital currencies.

For this study purpose, I also included some questions related to the aspect, if Bangladesh Government has allowed digital currencies what will the respondents opinion. From these questions, I found that-

- About $87 \%$ of respondents think that digital currency will help them in fast transactions, $77 \%$ of people think it will increase remittances, and $68 \%$ of people agreed that lack of digital currency causes additional cost for the freelancers and so on.

Having several advantages although digital currency possesses some threats for us.

- $84 \%$ of people think that Bangladesh doesn't have proper technologies for regulating digital currencies, further $75 \%$ of respondents fear the chances of money laundering in Bangladesh and as well $63 \%$ people's fright about fraudulence.

\section{Risks and Challenges of Digital Currency}

Successfully investing or trading in digital currency requires technical skills and at least a basic knowledge of how the blockchain works. Listed below are some important things that investors should pay attention to in this rapidly changing emerging industry. Some of the common risks associated with digital currencies such as loss or destroy private keys, Cyber security risks, Peer to peer transactions risk, loss of confidence, rules for preventing or restricting digital currency transactions, currency exchange risk, digital currency taxation, liquidity risk, risk of price changes, business hour risks, bankruptcy risks, and network slow down risks. The form of digital currency 
is not without some financial and security issues. To explore the challenges and problems of this virtual phenomenon this study has analyzed several studies and observed some digital currency sales forums. The main challenges of digital currency may include threats of security, crash problem in the system, real currency system, fluctuating value, chances of money laundering. In spite of having these issues mentioned in above, the use of digital currency can be promoted as a vital medium of the transaction in the future and this implication of the new provoking currency cannot be ignored.

\section{RECOMMENDATIONS}

Digital currency responds to real market demand and it is likely to stay with us for some time. The following action can be taken by the government to use digital currency in Bangladesh-

- Bangladesh should allow the Digital transaction platform for transactions to facilitate international trade in goods and services.

- Bangladesh Bank should conduct more studies on digital currency and the application of digital currency in the financial sector.

- Policymakers and regulators should not ignore digital currencies, or try to ban them. Both of these extreme methods are wrong. Regulators should consider digital currency as any other financial instrument based on its market importance, complexity and associated risk. Given its global and frontier nature, it is recommended that such rules be incorporated into all jurisdictions. Investments in digital currencies should be taxed in the same way as investments in other financial assets.

- As recently observed in Venezuela, digital currency could provide another opportunity for currency replacement.

- Advanced technology can bring a more transparent, secure and easy way to use a variety of digital currencies. This can increase the chances of effective competition between digital currency and sovereign currency.

\section{CONCLUSION}

Nowadays, the people are moving towards the digitization of everything. Digital currency is now a crying need in the financial sectors of Bangladesh. Digital currency can add an extra $3 \%$ of the total GDP of a nation and also digitalization of money can solve liquidity problems. Our study focused on the possible opportunities of digital currency in Bangladesh and also focused on its limitations. Observing the potential of digital currency, the emerging global demand is clearly visible, but since 201 Bank, Bangladesh Bank has limited digital currency in my country. Also, the survey concluded both positive and negative opinions whereas positive responses are noticeable. If we consider the prospects of digital currency of existing countries, this will encourage the use of digital currency in Bangladesh. From a detailed study, it's been clear that Bangladesh already has block-chain technology that could run digital currency. Proper initiatives by the government can ease the path of using digital currency by utilizing our existing block-chain technology. Hopefully, this study will help the government and all other concerned authorities to take action regarding digital currency. Due to data limitations from Bangladesh's perspective, only the theoretical part from our countryside has been presented here. Responses of respondents also demonstrated that there prevails a positive attitude of general people towards digital currency. Further study could be extended by observing the effect of digital currency on microeconomic variables. Overall, this study narrated that there are many possible ways to implement digital currency by following the countries successfully using this. Modifying some regulatory acts along with ensuring the security of transactions digital currency could be an attractive option. The study 
further states that if the government and policy makers take appropriate action, digital currency can have an impact on the financial sector, respectively.

\section{ACKNOWLEDGEMENT}

The authors would like to extend their heartfelt gratitude to Institute of Research and Training (IRT), Hajee Mohammad Danesh Science \& Technology University Dinajpur-5200, Bangladesh for providing financial supports.

\section{REFERENCES}

Altan, A., Karasu, S., \& Bekiros, S. (2019). Digital currency forecasting with chaotic metaheuristic bio-inspired signal processing techniques. Chaos, Solitons and Fractals, 126, 325-336. https://doi.org/10.1016/j.chaos.2019.07.011

Banu, B., Hossain, M. M., Haque, M. S., \& Ahmad, B. (2021). Effect of Microfinance Adoption on Rural Household Income in Selected Upazila of Kushtia District of Bangladesh. Bangladesh Journal of Multidisciplinary Scientific Research, 3(1), 24-32.

Castrén, O., Kavonius, I. K., \& Rancan, M. (2020). Digital Currencies in Financial Networks. European Banking Authority Staff Paper series, 8, 1-49.

Dwyer, G. P. (2015). The economics of Bitcoin and similar private digital currencies, Journal of Financial Stability, 17, 81-91. https://dx.doi.org/10.1016/j.jfs.2014.11.006

Ghosh, A., Gupta, S., Dua, A., \& Kumar, N. (2020). Security of Cryptocurrencies in blockchain technology: State-of-art, challenges and future prospects. Journal of Network and Computer Application, 163, 1-35. https://doi.org/10.1016/j.jnca.2020.102635

Gross, A., Hemker, J., Hoelscher, J., \& Reed, B. (2017). The role of secondary sources on the taxation of digital currency (Bitcoin) before IRS guidance was issued. Journal of Accounting Education, 39. https://dx.doi.org/10.1016/j.jaccedu.2017.02.001

Kanda, P., Burke, M., \& Gupta, R. (2018). Time-varying causality between equity and currency returns in the United Kingdom: Evidence from over two centuries of data. Physica A: Statistical Mechanics and its Applications, 506, 1060-1080. https://doi.org/10.1016/j.physa.2018.05.037

Li, D., Huang, J., \& Wang, L. (2019). The Impact of Digital Currency on the Financial System: Universal Decentralized Digital Currency, Is It Possible? Journal of Economics and Public Finance, 5(2), 203-218.

Su, C. W., Qin, M., Tao, R., \& Umar, M. (2020). Financial implications of fourth industrial revolution: Can bitcoin improve prospects of energy investment. Technological Forecasting \& Social Change, 158, 1-8. https://doi.org/10.1016/j.techfore.2020.120178

Saito, K., \& Iwamura, M. (2019). How to make a digital currency on a blockchain stable. Future Generation Computer System, 100, 58-69. https://doi.org/10.1016/j.future.2019.05.019 
Sapovadia, V., (2018). Financial Inclusion, Digital Currency, and Mobile Technology, Handbook of Blockchain, Digital Finance and Inclusion, 2, 361-385. https://dx.doi.org/10.1016/B978-0-12-812282-2.00014-0

Truby, J. (2018). Decarbonizing Bitcoin: Law and policy choices for reducing the energy consumption of Blockchain technology and digital currencies, Energy Research \& Social Science, 44, 399-410. https://doi.org/10.1016/j.erss.2018.06.009

Vandezande, N., (2017). Virtual currencies under EU anti-money laundering. Computer Law and Security Review, 33(3), 341-353. https://dx.doi.org/10.1016/j.clsr.2017.03.011

Zhu, C. \& Fu, Z. (2020). Regulatory Issues of Digital Currencies. Asian Research Journal of Mathematics, 16(5), 10-17.

\section{Copyrights}

Copyright for this article is retained by the author(s), with first publication rights granted to the journal. This is an open-access article distributed under the terms and conditions of the Creative Commons Attribution license (http://creativecommons.org/licenses/by/4.0) 